SHORT COMMUNICATION

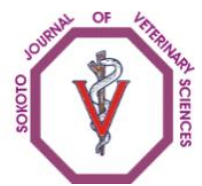

Sokoto Journal of Veterinary Sciences

(P-ISSN 1595-093X/ E-ISSN 2315-6201)

Danbirni et al/Sokoto Journal of Veterinary Sciences (2016) 14(1): 45-48

http://dx.doi.org/10.4314/sokjvs.v14i1.8

\title{
Prevalence of tuberculosis-like lesions in goats slaughtered at Bauchi central abattoir, Bauchi State
}

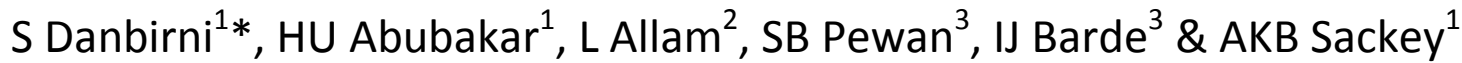 \\ 1. Department of Veterinary Medicine, Ahmadu Bello University, Zaria, Nigeria \\ 2. Veterinary Teaching Hospital, Ahmadu Bello University, Zaria, Nigeria \\ 3. National Veterinary Research Institute, Vom, Plateau State, Nigeria
}

*Correspondence: Tel.: +2348035968827, E-mail: drdanbirni07@yahoo.com

\begin{abstract}
Slaughter houses provide excellent avenues for detecting diseases of both economic and public health importance in livestock. A study of 12,429 slaughtered goats at the Bauchi central abattoir was carried out (from February to May, 2015) in order to determine the prevalence of tuberculosis-like lesions in slaughtered goats. The lesions were counted, visually examined and palpated during post mortem meat inspection. Of the 12,429 goats slaughtered and examined, tuberculosis-like lesions were observed in four (4) slaughtered goats with a prevalence of $0.03 \%$. It was concluded that although the prevalence was relatively low, the financial losses and public health implications of the finding should not be over looked.
\end{abstract}

Keywords: Abattoir, Bauchi State, Goat, Prevalence, Slaughtered Goats, Tuberculosis

Received: 26-11-2015

Accepted: 12-02-2016

\section{Introduction}

Goat (Capra hircus) as known in different parts of the world is one of the smallest domesticated ruminant which have been with mankind for many generations. The important role of goats in production of milk, wool and manure is well documented (Devendra, 1999). Goats are prolific and require low input for moderate level of production. They reach maturity at early age and are nutritionally and financially profitable to keep for production (Devendra \& Burns, 1970). Tuberculosis (TB) in goats has not been extensively investigated in comparison with cattle in Nigeria. Tuberculosis in goat and sheep is caused by members of Mycobacterium tuberculosis complex predominantly Mycobacterium bovis and Mycobacterium caprae (Crawshaw et al., 2008) and in some cases by Mycobacterium tuberculosis (Cadmus et al., 2009). In goats, the disease normally spread through head to head contact, which will include sharing of contaminated haystacks and water bowls as well as infected aerosols spread from breath. Tuberculosis can affect the udder in which case the milk is infective until or unless is pasteurized. Infected sputum coughed up can be swallowed and thus infect the gastrointestinal tract. Most commonly in goats, the cough is usually seen as a chronic cough which is unresponsive to treatment and may be accompanied by gradual loss of weight and sometimes diarrhoea (Aranaz et al., 2003). The Predilection site for tuberculosis in goats is the lower respiratory tract and the associated lymph nodes (Daniel et al., 2009).

Epidemiological studies have indicated that tuberculosis in goat and sheep has a wide global distribution, being reported in several countries of the world including New Zealand, Sudan, Spain, Nigeria, the United Kingdom, Italy, Algeria and Ethiopia (Aranaz et al., 1999).

Caprine tuberculosis poses a risk to goat health and production in developing world (Cadmus et al., 2009). There has been recent increase in caprine tuberculosis in several countries; even in those practicing a long standing test and slaughter policy (Cadmus et al., 2009). It is reported that the infection is widespread in Africa where goats cograze with cattle that were not subjected to tuberculosis testing and slaughter protocols (Aranaz et al., 2003). Goats may also become infected with Mycobacterium bovis when sharing pastures with infected cattle, at watering points, market places and shared night shelters (Naima et al., 2011).

Report on possible tuberculosis in goats in Nigeria was made by Ojo (1994) on the basis of gross lesions without culture confirmation. Livestock 
owners in Nigeria normally graze cattle and goats together, and this practice poses a high risk for transmission of bovine TB among these animals (Ojo, 1994). This practice is especially a threat to goats in Nigeria because of several reports on bovine TB in cattle in Nigeria (Alhaji, 1976; Cadmus et al., 2006; Abubakar, 2007; Danbirni et al., 2010). However, reports on diagnosis of TB in goats in Nigeria are scanty (Cadmus et al., 2009). There is need for awareness on the extent to which the public is exposed to certain zoonotic diseases detected in abattoirs and the financial losses through condemnation of affected organs and carcass especially due to tuberculosis in goats ( $\mathrm{Nfi}$ \& Alonge, 1987).The aim of this study therefore was to determine the prevalence of tuberculosislike lesions in goats slaughtered at Bauchi central abattoir of Bauchi State, Nigeria.

\section{Materials and Methods}

Study site and animals

The study was carried out in Bauchi central abattoir located along Gombe road in Bauchi State. Bauchi town is located between $9^{\circ} 3^{\prime \prime}$ and $12^{\circ} 3^{\prime} \mathrm{N}$ and $8^{\circ} 50^{\prime \prime} \mathrm{E}$ of the Sudan Savannah of Northern Nigeria. The abattoir is owned by the state Government and various species of domestic animals such as goats, sheep, cattle and camel are slaughtered daily. Most of the goats slaughtered are of indigenous Nigerian breeds (Sokoto Red, Kano Brown and West African Dwarf) with Sokoto Red and Kano Brown being in majority. The goats for slaughter are being purchased at different nearby local markets and transported to the abattoir. According to the abattoir records of 2015, an average of 300 goats of varying ages and breeds were slaughtered daily in Bauchi central abattoir.

\section{Study design and sampling}

The study was conducted over four (4) months period (February to May, 2015). Visits were made to the abattoir during weekends at 6:00am before ante mortem examination and slaughter. The number of goats brought to the abattoir was recorded and a total of 12,429 slaughtered goats were examined during the period of the study. Examination of lesions similar with tuberculosis in the slaughtered goats was conducted.

\section{Post mortem examination}

Postmortem inspection was performed based on the principle of meat inspection - Visualization, Palpation and Incision (Umoh et al., 2005) in order to observe for the presence of granulomatous lesions that were descriptive of tuberculosis. The seven lobes of the two lungs of the goat, (left apical, left cardiac, left diaphragmatic, right apical, right cardiac, right diaphragmatic and right accessory lobes) were inspected, palpated and incised. The carcass including internal organs such as liver, kidneys, mammary gland, intestines and lymph nodes were inspected and palpated. Lymph nodes were not incised for fear of contaminating the carcasses and the environment.

The cut surfaces of the organs were thoroughly examined for the presence of abscesses, cheesy masses and tubercles as described by Corner (1994). Where gross lesions suggestive of tuberculosis were found in any of the tissues, the animal was classified as having tuberculosis-like lesions. The prevalence of tuberculosis-like lesions in the goats slaughtered at the abattoir was expressed as percentage i.e prevalence equals the total number of goats with tuberculosis-like lesions divided by the total number of goats slaughtered multiplied by 100 (Danbirni et al., 2013).

\section{Results and Discussion}

The result of this study showed that a total of 12,429 goats were slaughtered out of which 4 $(0.03 \%)$ were observed to have TB lesions. This means 4 per 10,000 slaughtered goats were positive. The highest number of goats slaughtered was in the month of May with a prevalence of 0.05 $\%$ while February had the lowest number of slaughtered goats with a prevalence of $0.05 \%$ (Table 1).

Table 1: Prevalence study of tuberculosis-like lesions in slaughtered goats in Bauchi Central abattoir of Bauchi State

\begin{tabular}{cccc}
\hline Months & $\begin{array}{c}\text { Total no. of } \\
\text { slaughtered goats }\end{array}$ & $\begin{array}{c}\text { No. of slaughtered goats with } \\
\text { TB-like lesions }\end{array}$ & $\begin{array}{c}\text { Prevalence of TB-like lesions per 10, } \\
\text { 000 slaughtered goats }\end{array}$ \\
\hline February & 2,016 & 1 & 5 \\
March & 3,512 & 0 & 0 \\
April & 3,143 & 1 & 3 \\
May & 3,758 & 2 & 5 \\
Total & $\mathbf{1 2 , 4 2 9}$ & $\mathbf{4}$ & $\mathbf{3}$ \\
\hline
\end{tabular}


A prevalence of 4 positive cases per $10,000(0.03$ $\%)$ slaughtered goats was obtained during the study period. The prevalence in this study is lower compared to the work of Cadmus et al. (2008) who reported a prevalence of $0.3 \%$ in Bodija Municipal abattoir, Ibadan. The difference in the prevalence could be attributed to the short period of the present study (i.e. 32 days) thereby possibly limiting the amount of data to be obtained in determining the true prevalence of the disease.

Furthermore, the high prevalence reported in Ibadan could be attributed to the longer duration of the study and the use of more sensitive diagnostic technique (deletion typing). More so, the prevalence of $0.03 \%$ observed in this study was relatively low compared to the work of Hiko \& Agga, (2011) who reported a prevalence of $4.2 \%$ in goats slaughtered at Mdjo abattoir in Ethiopia and also that of Tafesse et al. (2011) who reported a

\section{References}

Abubakar IA (2007). Molecular epidemiology of human and bovine tuberculosis in the Federal Capital Territory and Kaduna State, Nigeria. Ph.D. Thesis, Plymouth University, UK. Pp 1-134.

Alhaji I (1976). Bovine tuberculosis in four northern states of Nigeria. Ph.D. thesis, Ahmadu Bello University, Zaria, Nigeria. Pp 1-236.

Aranaz A, Liébana E, Gómez-Mampaso E, Galán JC, Cousins $D$, Ortega A, Blázquez J, Baquero $F$, Mateos A, Súarez $G$ \& Domínguez L (1999). Mycobacterium tuberculosis subsp. caprae subsp. nov.: a taxonomic study of a new member of the Mycobacterium tuberculosis complex isolated from goats in Spain. International Journal of Systematic and Evolutionary Microbiology, 49(3): 1263-1273.

Aranaz A, Cousins D, Mateos A \& Dominguez L (2003). Elevation of Mycobacterium tuberculosis subsp. caprae to species rank as Mycobacterium caprae comb. nov., sp. nov. International Journal of Systemic and Evolutionary Microbiology, 53(6): 17851789.

Cadmus SI, Adesokan, HK, Jenkins AO \& Soolingen D (2009). Mycobacterium bovis and Mycobacterium tuberculosis in goats, Nigeria. Emerging Infectious Diseases, 15(12): 2066-2067.

Cadmus SI, Palmer S, Okker M, Dale J, Gover K, Hewinson RG \& Gordon SV (2006). Molecular analysis of human and bovine tubercle bacilli from a local setting in Nigeria. Journal of Clinical Microbiology, 44(1): 29-34. prevalence of $3.1 \%$ in goat using single intradermal tuberculin skin test in the same abattoir. Silvano et al. (2011) reported a prevalence rate of $1.46 \%$ in 822 goats screened for TB. This could be attributed to the difference in exposure to TB-infected animals, the occurrence of animal TB in the geographical locations, techniques employed and duration of the studies.

In conclusion, the overall prevalence of tuberculosis-like lesions in slaughtered goats in this study was $0.03 \%$, revealing a relatively low prevalence of potential TB in goats slaughtered at Bauchi central abattoir. Although the rate of identification is moderately low, the risk and public health importance of potential TB in goats should not be overlooked. Further studies needs to be carried out in other abattoirs within Bauchi State in order to established the prevalence of caprine tuberculosis in the State.

Cadmus SIB, Adesokan HIC \& Awosanya AEJ (2008). Public issues and observations made during meat inspection at Bodija municipal abattoir, Ibadan, Oyo state of Nigeria. Nigerian Veterinary Journal, 29(2): 43-47.

Corner LA (1994). Post mortem diagnosis of Mycobacterium bovis infection in cattle. Veterinary Microbiology 1(40): 53-63.

Crawshaw T, Daniel R, Clifton-Hadley R, Clark J, Evans H \& Rolfe $S$ (2008). "Tuberculosis in goats caused by Mycobacterium bovis. Veterinary Record, 163(4): 127.

Danbirni S, Pewan SB, Onoja II, Ababa JA \& Okaiyeto SO (2013). A five year retrospective study of bovine tuberculosis granulomatous lesions in slaughtered cattle in Adamawa state, Nigeria. Journal of Veterinary Advance, 3(12): 313-318.

Danbirni S, Sackey AKB, Ayo JO \& Bawa EK (2010). Exposure and shedding in milk of Mycobacterium bovis in dairy herds using one-step anigen rapid bovine tuberculosis antibodies test and Ziehl-Neelsen stain. Veterinary Research 3(3): 38-42.

Daniel R, Evans H, Rolfe S, de la Rua-Domenech R, Crawshaw T, Higgins RJ, Schock A, \& Clifton-Hadley R (2009). Outbreak of Tuberculosis caused by Mycobacterium bovis in Golden Guernsey goats in Great Britain. Veterinary Record, 165(12): 335342.

Devendra C \& Burns M (1970). Goats production in the tropics. Commonwealth Bureau of Animal Breeding and Genetics, Farnham Royal, Edinburgh, England. Technical Communication, 19 (12): 184. 
Devendra C (1999). Goats challenges for increased productivity an improved livelihoods, Outlook on Agriculture, 28(4): 215-226.

Hiko A \& Agga GE (2011). First-time detection of Mycobacterium species from goats in Ethiopia. Tropical Animal Health and Production, 43(1): 133-139.

Naima S, Borna M \& Bakir M (2011). TB in cattle and goat of North Algeria. Veterinary Research, 4(4): 100-103.

Nfi AN \& Alonge DO (1987). An economic survey of abattoir data in Fako division of Southwest province of Cameroon.19781980. Bulletin Animal Health and Production for Africa, 35(4): 239-242.

Ojo SA (1994). A survey of pathological conditions in slaughtered goats at Zaria slaughter house. In: Small Ruminant Research and Development in Africa: Proceedings of the Third Biennial Conference of the African Small Ruminant Research Network, UICC.
Kampala, Uganda; 5-9 Dec. 1994; ILRIInternational Livestock Research Institute, Nairobi, Kenya. (SHB Lebbie \& E Kagwini, editors). Pp 139-141.

Silvano SSH, Pinheiro SR, de Souza CCD, do Rosario PAM, Alves CJ \& de Azevedo SS (2011). Mycobacterium bovis infection in goats from the northeast region of Brazil. Brazil Journal of Microbiology, 42(4): 14371439.

Tafesse K, Dawo F, Sori T \& Ameni G (2011). Prevalence of caprine tuberculosis in midrift valley area of Oromia, Ethiopia. African Journal of Microbiology Research, 5(12): 1473-1478.

Umoh JU, Kabir J, Okolocha EC, Dzikwi AA, Egege SC, Kwaga JKP, Mosimabale FO \& Oni OO (2005). A Manual for Clinic in Veterinary Public Health and Preventive Medicine, $\mathrm{Pp}$ 43-51. 